\title{
Farmers Knowledge on Pesticide Safety Management in Ponorogo
}

\author{
Eka Rosanti ${ }^{1, *}$ Ratih Andhika Akbar Rahma ${ }^{2}$ Mahmudah Hamawi ${ }^{3}$ Dian Afif Arifah ${ }^{4}$ \\ 1,2,4 Occupational Safety and Health Department, Universitas Darussalam Gontor \\ ${ }^{3}$ Agrotechnology Department, Universitas Darussalam Gontor \\ *Corresponding author.Email: ekarosanti@unida.gontor.ac.id
}

\begin{abstract}
Agricultural activities in PonorogoDistrict are one of the largest contributors to the economy. However, agricultural activities related to pesticide use need attention. Based on the previous research, there were $36.7 \%$ of farmers in one of the villages in Ponorogo District were at a very high risk of pesticide contamination. This study aims at analyzing farmers' knowledge of pesticide safety management. This descriptive study involved 57 farmers in village $\mathrm{X}$ in Ponorogo. The used instrument was a questionnaire to find out the level of knowledge of farmers. The researchers also conducted semi-structured interviews to know pesticide usage more objectively. The data showed that $95 \%$ of farmers had poor knowledge about pesticide safety management; this was reinforced by the analysis result of every question item which describes that the habit on personal equipment and personal hygiene was still poor. There were only 5,26\% of the farmers who had a good level of knowledge about pesticide safety management. The Pesticide is handled based on habits instead due to the lack of supervision, technical skills and personal protective equipment. Thus, the effectiveness of the application of pesticide safety management needs assistance from the relevant stakeholders for the building of knowledge, skills, and provision of facilities.
\end{abstract}

Keywords: Farmers, Knowledge, Pesticide management

\section{INTRODUCTION}

The area of agricultural land in Ponorogo District is $5,119,905$ with the number of farmers amounting to 27,755 [1]. It means that Agricultures are one of the important economic supports in Ponorogo. Agricultural cover rice, soybeans, and horticulture such as vegetables, fruits, onions, chilies, and corn. In agricultural activities, farmers need to eliminate crop pests to get maximum yield. Therefore, farmers use pesticides both organic and inorganic. Most farmers in Ponorogo use inorganic pesticides containing chemicals as it can be more potent at killing pests than the organic one.

The spraying activities of horticultural farming more intensive than rice. Farmers spray one to 2 times a week during the harvest period. These can increase the risk of pesticide contamination in farmers' blood. The higher the direct exposure of pesticide use, the higher levels of pesticide in the blood is [2][7][8]. Along with this fact, the personal health of farmers becomes an important concern to take care of.

Inorganic pesticides are very harmful to the human body, the environment, and agricultural products in short and long termeffects [3][6][13]. Danger to body health can occur due to the accumulation of pesticides in the blood [2][3][4]. Symptoms that occur when the body is exposed to pesticide exposure are dizziness, difficulty breathing, skin irritation, and limpness. Pesticide contamination in the blood can result in birth defects, cancer, hormonal change, reproductive disorders, dermatological, gastrointestinal, nervous system damage, and lead to death [6][7][8]. Cholinesterase inhibition becomes one of the biomarkers of pesticide levels in the blood [7].

Based on data in 2018, 36.7\% of farmers in Village X was at a very high risk of blood pesticide contamination [9]. Based on initial observations, most farmers did not use Personal Protective Equipment (PPE) in pesticide management. Therefore, researchers intend to explore one of the factors related to pesticide levels in the blood i.g. the level of farmer's knowledge about pesticide safety management [4]. Pesticide safety management is one of the keys to maintain the health of farmers from contamination [6]. Based on the study, the knowledge level of pesticide usage is significantly related with the practice [4]. The purpose of this study is to analyze the knowledge of farmers as well as comprehend the practice of implementing inorganic pesticides on the land. This study is expected to provide recommendations on pesticide safety management to improve the degree of health of farmers.

\section{METHOD}

This research was a descriptive study. It involved 57 farmers in $\mathrm{X}$ village of Ponorogo who were randomly selected by simple random sampling technique. The farmers willing to be the subject must have filled the informed content. Samples represented the 5 existing farmer groups and there was only one woman in the sample. 
The farmers consisted of rice farming, horticulture, and mix (rice and horticulture). Farmers' knowledge about pesticide safety management was obtained through a questionnaire divided into high $(\geqslant 80 \%)$, moderate $(60-80 \%)$, and poor $(<60 \%)$. The researchers also conducted semi-structured interviews to know pesticide usage more objectively. Analysis of pesticide management using cross-tabulation ranging from pesticide purchase, storage, mixing, handling, disposal of used pesticide bottles, completeness of personal protective equipment used, and personal hygiene. This research had been approved by the ethics commission of Dr. Harjono Hospital of Ponorogo with registered number : $3502021 \mathrm{~K} 121442020082100002 / \mathrm{IX} / \mathrm{KEPK} / 2020$.

\section{RESULT}

The following is the demographic characteristic data of farmers in village $\mathrm{X}$ :
The graph bellow shows the practical habits of pesticide usage in farmers:

Figure 1 Pesticide safety management knowledge Level

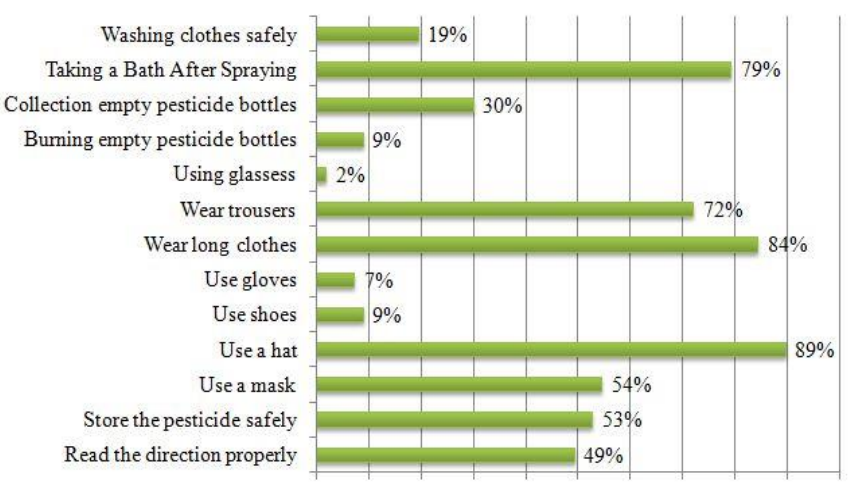

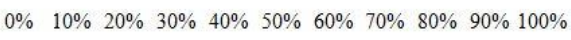

Table 1. Demographic of farmers

\begin{tabular}{|l|c|c|c|c|c|}
\hline \multirow{2}{*}{$\begin{array}{l}\text { Demographic } \\
\text { Characteristic }\end{array}$} & Good & Moderate & Poor & Total & Number (\%) \\
\cline { 2 - 5 } Age & & & & & \\
\hline$<40$ & 1 & 4 & 2 & 7 & 12,28 \\
\hline$\geq 40$ & 2 & 28 & 20 & 50 & 87,72 \\
\hline Length of Year & & & & & \\
\hline$<10$ & 3 & 30 & 19 & 52 & 9,77 \\
\hline$\geq 10$ & 1 & 2 & 1 & 4 & 7,23 \\
\hline Education & 0 & 12 & 12 & 23 & 40,35 \\
\hline Illiterate & 2 & 6 & 4 & 12 & 21,05 \\
\hline Primary School & 0 & 11 & 5 & 16 & 28,07 \\
\hline Secondary School & 0 & 1 & 1 & 2 & 3,51 \\
\hline High School & 0 & & 3 & 5 \\
\hline College & & & & \\
\hline
\end{tabular}

The results of collecting data on farmers' knowledge of pesticide safety management using questionnaires are as follows:

Figure 1 The farmers pesticide management

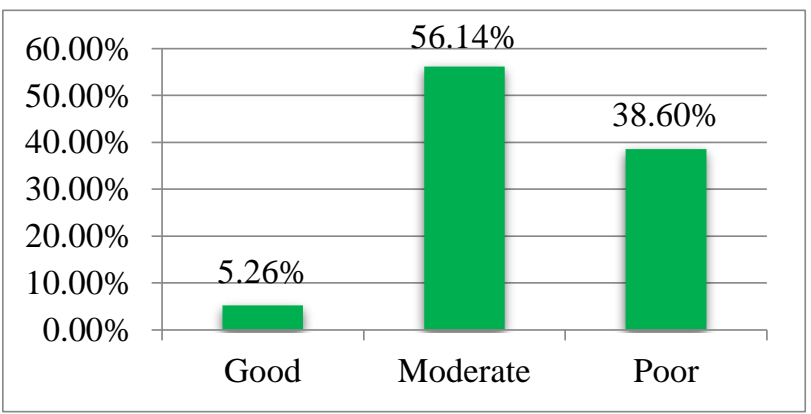

\section{DISCUSSION}

Based on the results. It was known that the knowledge of farmers in Village $\mathrm{X}$ about pesticide safety management was poor. Concerning the results of the semi-structured interview, $68 \%$ of farmers had not obtained building knowledge or socialization on how to use inorganic pesticides safely and correctly. During this time farmers utilized pesticides based on hereditary habits. Most people had worked as farmers since they were teenagers and even from childhood.

Building the knowledge and provision of personal protective equipment was essential for pesticide safety management in order to reduce health risks in farmers [7]. Poor knowledge makes unsafe pesticide management occurred repeatedly [8]. The above findings were also supported by farmer demographic data including $87.72 \%$ of 
farmers were at $\geq 40$ years old, $91.23 \%$ had a working period $\geq$ of 10 years and only $28.07 \%$ of farmers joined high school.

\subsection{Analysis of Farmer Knowledge Based on Demographic Characteristics}

At the age of $<40$ years old, there were 1 wellknowledgeable farmer, 4 medium knowledgeable farmers, and 2 poor knowledgeable farmers. These phenomena showed the importance of imparting knowledge at all ages. Previous research had suggested that farmers at a young or old age were not a measure for safety indicators [2]. Farmers with good knowledge were in the working period of $\geq 10$ years as the use of pesticides for a long time could increase pesticide safety management awareness [4][14].

Two farmers who had a good level of knowledge were at the age of $<40$ years old with secondary school education and the age of $\geq 40$ was 1 people with illiterate and 1 person at the high school level. These suggest that young and old farmers were equally exposed to pesticides that were harmful to the health of the body [7]. In addition, higher education did not guarantee farmers' awareness of pesticide hazards due to hereditary habits and lack of building knowledge, provision of facilities and infrastructure as well as lack of assistance and supervision from related stakeholders. Without guidelines and assistance, farmers performed high doses of pesticides and more often suppress crop pests [10].

Based on the results of interviews of three farmers who had good knowledge, two of them took secondary school education and one illiterate person had participated in socialization activities organized by the Ponorogo District Agriculture Office. There were 18 people or $32 \%$ of farmers who have had socialization about the use of good pesticides, but only 3 people had good knowledge. The effectiveness of socialization depended on each individual's capture and confidence level [10]. Socialization with specific themes, accurate information, and the management of pesticides could technically increase farmers' awareness of pesticide hazards [4][5][6]. Based on the results of the interview, farmers only got socialization without technical skills.

\subsection{Analysis of Pesticide Use Practices in Farmers}

Knowledge and practical use of pesticides were two simultaneous things. Poor knowledge made farmers' performance in unsafe and unhealthy ways. This increased the risk of health [4] [11]. The poorest practice was the use of personal protective equipment followed by personal hygiene.

There were $49 \%$ of farmers who read pesticide labels, yet in practice, it is still in accordance with the habits. Farmer habits were more trusted than knowledge, farmers prefer their own opinions based on experience. As a result, farmers often mixed 2, even more pesticides to facilitate them in eradicating pests without understanding the reaction of the chemical content of each pesticide. Labels on pesticide packaging were important information in safe use for the health and environment [9].

There were $53 \%$ of farmers who stored pesticides in rice fields and $47 \%$ stored at home. Storing pesticide bottles in the house was particularly risky for contamination of other family members, especially children, and to nearby objects, through inhalation of residual exposure when preparing and mixing [3][8][14]. Farmers kept at home for fear of being lost if put on the field.

The use of personal protective equipment on mixing, carrying, or spraying becomes one of the factors of pesticide contaminations in the body [3][7]. During this time farmers only used hats and masks with clothes tied to the mouth and nose. Clothes and trousers were still impenetrable to pesticides, and previous research had also suggested that improper use of personal protective equipment increased the risk of pesticides to health [4][6]. Pesticides got into the body through inhalation, skin, and oral. Some previous studies had mentioned that pesticide residues were found on hands, dermal patches, and face protectors or shields [4][7]. The reason farmers did not use personal protective equipment properly was related to funds. Thus, there should be attention from the relevant stakeholders for the procurement of personal protective equipment in order to safe pesticide handling [11].

There were $61 \%$ of farmers who disposed of pesticides bottles in rice fields and rivers, and this certainly harmed the environment and contaminate the body of water that was the main life source of humans as well as the surrounding animals [6][8][14]. According to previous research, it was found that humans could be exposed to pesticides from contaminated water [11].

There were $79 \%$ of farmers immediately took a shower after spraying, but it was carried out at home as well as washing clothes along with the dirty clothes of family members. It can increase the risk of contamination with family members at home [3]. Also, leaving pesticides within a few moments after spraying can increase the absorption of pesticide levels into the body through the skin [4][6]. The transfer of pesticide residues through pesticidecontaminated clothing from field to home was called the take-home pesticide exposure pathway [12].

\section{CONCLUSION}

Based on the text above, it can be stated that the poor knowledge of pesticides in farmers occurs due to a lack of assistance from related stakeholders, inadequate facilities, and the strong hereditary farming culture. Pesticide safety management was key in preventing pesticide contamination in the blood. Therefore, it required socialization about the integration of agriculture with pesticide safety management and comprehensive assistance from related stakeholders, especially the Department of Health and the Department of Agriculture on the use of good, safe, and technically correct pesticides [6][8][10][14], starting from purchasing, storage, mixing, handling, disposal of used pesticide bottles, completeness of personal protective equipment and 
personal hygiene [3]. Supervision and inspection every six months was also necessary to ensure the continuity of the program or good practice [4][5]. Some previous studies had explained that farmers gaining socialization and training had higher knowledge and safety behavior on pesticide use [10]. Pesticide hazard building is also required to be done early on informal education integrated into the curriculum to improve safety behavior early on [11].

\section{AUTHORS' CONTRIBUTIONS}

All authors conceived of the presented idea. The first and third authors developed the theory. The second and fourth authors verified the analytical methods. All authors discussed the results and contributed to the final manuscript.

\section{ACKNOWLEDGMENTS}

The researchers would like to express the gratitude tothe Ministry of Research (BRIN) for providing grants to the research team in 2020.

\section{REFERENCES}

[1] Badan Pusat Statistik Kabupaten Ponorogo, Katalog Statistik Daerah Kabupaten Ponorogo 2015. Badan Pusat Statistik Kabupaten Ponorogo, 2015.

[2] D. A. Rahman, Zakianis, and L. Fitria, Pesticide Exposure, Behavior of Farmer, and Activity of Cholinesterase Enzyme in Blood of Fertile WomenFarmers, Jurnal Kesehatan Masyarakat Nasional, vol. 10(2), 2015, pp. 51-56. DOI: http://dx.doi.org/10.21109/kesmas.v10i2.879.

[3] C. A. Damalas and I. G. Eleftherohorinos, Pesticide Exposure, Safety Issues, and Risk Assessment Indicators, Int. J. Environ. Res. Public Health, vol. 8, 2011, pp. 1402-1419. DOI: 10.3390/ijerph8051402.

[4] S. Santaweesuk, P. Boonyakawee, and W Siriwong, Knowledge, Attitude and Practice of Pesticide Use and Serum Cholinesterase Levels Among Rice Farmers in Nakhon Nayok, Province, Thailand, Journal of Health Research, 2020. DOI: https://doi.org/10.1108/JHR09-2019-0204.

[5] P, Boonyakawee, S, Taneepanichskul, R. S. Chapman R. S, Effects of An Intervention To Reduce Insecticide Exposure On Insecticide-Related Knowledge And Attitude: A Quasi-Experimental Study In ShogunOrange Farmers In Krabi Province, Thailand, Risk Manag Healthc Policy, 6, 2013, pp. 33-41. DOI: 10.2147/RMHP.S50409.

[6] V. A. Sefa, E. A. Bediako, L. Kenyon, and J. A. Micah, Pesticide Use Practices and Perceptions of Vegetable Farmers in the Cocoa Belts of the Ashanti and Western Regions of Ghana, Adv Crop Sci Tech, vol. 3(3), 2015, pp. 1-10. DOI: 10.4172/23298863.1000174 .

[7] J. A. Kapeleka, E. Sauli, O. Sadik, and P. A. Ndakidemi, Biomonitoring of Acetylcholinesterase (AChE) Activity among Smallholder Horticultural Farmers Occupationally Exposed toMixtures of
Pesticides in Tanzania, Journal of Environmental and Public Health, 2019, pp. 1-11. DOI: https://doi.org/10.1155/2019/3084501.

[8] J. P. Rijal, R. Regmi, R. Ghimire, K. D. Puri, S. Gyawaly, and S. Poudel, Farmers' Knowledge on Pesticide Safety and Pest Management Practices: A Case Study of Vegetable Growers in Chitwan, Nepal, Agriculture, Vol. 8(16), pp. 1-11, 2018. DOI: https://doi.org/10.3390/agriculture8010016.

[9] Y. D. Andarini and E. Rosanti, Study of Toxicity Pesticide Based on Length of Work and Personal Hygiene on Horticultural Farmers in Demangan Village, An-Nadaa, vol. 5(2), 2018, pp. 82-89. DOI: http://dx.doi.org/10.31602/ann.v5i2.1655.

[10] C. A. Damalas and S. D. Koutroubas, Farmers' Training on Pesticide Use Is Associated with Elevated Safety Behavior, Toxics, vol. 5(19), 2017, pp. 1-10. DOI: 10.3390/toxics5030019.

[11] B. Ndayambaje, H. Amuguni, J. Con-Schmitt, N. Sibo, M. Ntawubizi, and E. VanWormer, Pesticide Application Practices and Knowledge among SmallScale Local Rice Growers and Communities in Rwanda: A Cross-Sectional Study, International Journal of Environmental Researchand Public Health, 16(4770), 2019, pp. 1-11. DOI: https://doi.org/10.3390/ijerph16234770.

[12] C. Thao, N. Burke, S. Ha, and A. Joyce, Pesticide Knowledge, Attitudes, and Practices Among SmallScale Hmong Farmers in the San Joaquin Valley of California, Journal of Integrated Pest Management, Vol. 10(1), 2019, pp. 1-6. DOI: 10.1093/jipm/pmz030.

[13] A. H. Oesterlund, J. F. Thomsen, and E. Jors, Pesticide knowledge, practice and attitude and how it affects the health of small-scale farmers in Uganda: a crosssectional study, African Health Sciences, vol 14(2), 2014, pp. 420-433. DOI: 0.4314/ahs.v14i2.19.

[14] M. V. S. Sai, G. D. Revati, and M. M. Kumar, Knowledge and Perception of Farmers Regarding Pesticide Usage in a Rural Farming Village, Southern India, Indian J Occup Environ Med, vol. 23(1), 2019, pp. 32-36. DOI: 10.4103/ijoem.IJOEM_121_18. 